\title{
原著 II
}

\section{オリゴヌクレオチドプローブを用いたクローン病 糞便中腸内細菌叢の検討}

\author{
東京医科大学第 4 内科 \\ 渡 辺 浩一
}

近年, バクテロイデス属の種の変動と炎症性腸疾患との関連性が注目されているが, 菌種を 同定することは実際には困難なことが多い. 今回, Bacteroides fragilis, B. vulgatus, B. distasonis, B. eggerrthii, B. caccae に特異的な DNA プローブを作成し，クローン病 (CD) 6 症例 7 検体におけるバクテロイデス属の種の変動を検討した. CD 群における菌数 は対照群に比べ各菌種とも減少したが，菌種の割合は，対照群でB. vugatus が51.9\%と最も 高く, 次いでB. caccae 19.3\%, B. eggerrthii 13.0\%, B. fragilis 8.1\%であったが, CD 群では B. vulgatus 2.6\%, B. caccae 0.06\%, B. eggerrthii $0 \%(\mathrm{P}<0.01)$, B. other 0.01\%（P<0.05）が有意に減少したのに対し, B. frafilis が97.3\%と有意 $(\mathrm{P}<0.01 ）$ に 増加するとともにその大半を占め, B. fragilis のクローン病の病態への関与が示唆された.

索引用語 : 腸内細菌叢, バクテロイデス，クローン病，DNA プローブ

\section{緒言}

これまで,クローン病における糞便中腸内細菌 には Bacteroides fragilis group (とくにB. fragilis, B. vulgatus, B. distasonis) が最優 勢に出現し，その他の嫌気性菌では E. rectale, C. ramosum が高率に分離され，好気性菌では E. coli, Klebsiella pneumoniae が高率に分離 されると報告されている1．バクテロイデス属は 1990年に Bacteroides fragilis, B. vulgatus, B. ovatus, B. caccae, B. thetaiotaomicron, B. distasonis, B. uniformis, B. stercoris, B. merdae, B. eggerrthii の10菌種に分類さ れ2), クローン病において最優勢菌であるこれら バクテロイデス属の種の変動を検討することは重 要なことと考えられる. しかし腸内フローラはそ の構成が複雑であり, 正確な菌種の同定となると 熟練した研究者の手に委ねざるをえない場合が多
く，このことが消化管疾患と細菌との関連性を研 究する際の妨げとなっていることは否定できな い. 近年, 細菌の 16 S-rRNA に対し相補的な DNA プローブを用いたハイブリダイゼーション 法を用いることにより，比較的容易に菌種が同定 可能となった。 そこで今回，七卜攸便中より分離 されるバクテロイデスのうち，10種の菌種に対す る DNA プローブを作成してその種特異性を検 討し, 加えてクローン病におけるバクテロイデス 属の種の変動について検討した.

\section{I. 対象および方法}

\section{1. 臨床材料 (Table 1)}

平成 5 年 12 月から平成 6 年 9 月までの間に当院 で治療した活動期クローン病患者（以下 CD） 6 症例 7 検体之, 対照（健康成人）10症例10検体上 り得られた新鮮粪便 $1 \mathrm{~g}$ を, 光岡の方法3)に準じ て培養, 同定した. Table 1 にその内訳を示 
Table 1 Objects of study

\begin{tabular}{lcc}
\hline & Control & Crohn's disease \\
\hline Case & $10(10)$ & $6(7)$ \\
Age & $27 \pm 3.7$ & $26.6 \pm 5.0$ \\
Sex & 이 $:$ 우 $=9: 1$ & $\sigma^{7}:$ 우 $=5: 2$ \\
\hline & & ( ) : Number of samples
\end{tabular}

す. 菌数は集落 $1 \mathrm{~g}$ 当たりの常用対数で示し, 統 計学的検討は $\mathrm{t}$ 検定および $\chi^{2}$ 検定により行っ た。

\section{2. 菌株 (Table 2)}

標準株として, American Type Culture Collection（以下 ATCC）より入手した Bacteroides fragilis ATCC 25285, B. vulgatus ATCC 8482, B. thetaiotaomicron ATCC 29148, B. ovatus ATCC 84836, B. distasonis ATCC 8503, B, merdae ATCC 43184, B. uniformis ATCC 8492, B. stercoris ATCC 43183, B. eggerrthii ATCC 27754, B. caccae ATCC 43185, Streptococcus thermophilus ATCC 19258, Bifidobacterium breve ATCC 15700 , B. longum ATCC 15707, Eubacterium aerofaciens ATCC 25986, Peptococcus productus ATCC 27340, P. prevotii ATCC 9321, Clostridium difficile ATCC 17859, C. innocuum ATCC 14501, Veillonella alkalescens ATCC 17745, Enterobacter intermedium ATCC 33110, E. cloacae ATCC 1304, Prevotella melaninogenica ATCC 25845を用 い, 野外株として Bacteroides vulgatus ATCC 29327, B. vulgatus ATCC 31376, Eubacterium biforme VPI 19218を用いた，またこの他 に使用した Lactobacillus acidophillus, L. casei, Streptococcus lactis, Enterococcus faecalis, E. faecium はヤクルト中央研究所よ り入手した。

3. 16 S-rRNA の抽出

今回使用した菌種をすべて $1 \%$ glucose 添加 GAM 液体培地（日水製薬） $100 \mathrm{~m} \ell$ 中で嫌気的に 一晚培養した後， $3,000 \mathrm{rpm}, 4{ }^{\circ} \mathrm{C}$ にて20分間遠 心を行った，遠沈成分を洗浄溶液（50mM Tris 〔pH7.4, $1 \mathrm{mM}$ EDTA) にて 2 回洗浄し, 10 \% sucrose $2 \mathrm{~m} \ell$ を加え, $50 \mathrm{mg} / \mathrm{m} \ell$ の lysozyme 80 $\mu \ell に て$ 処理した。次に, CETA $(500 \mathrm{mM}$ EDTA〔pH8. 0]) $800 \mu \ell$ と $20 \% \operatorname{SDS} 800 \mu \ell$ を 加えた，蛋白成分を除去するために，緩衝液

(TE : 10mM Tris [pH8.0], 1 mM EDTA) で平衡化した等量の phenol による処理を 3 回 行った。水層を等量の chloroform/isoamil alcohol（24:1）で抽出し，3 倍量の無水 etha-

Table 2 Microorganisms used in this study

\begin{tabular}{|c|c|c|c|}
\hline Species & Strain & Species & Strain \\
\hline 1 Bacteroides fragilis & ATCC 25285 & 15 Escherichia coli & ATCC 11775 \\
\hline 2 Bacteroides vulgatus & A TCC 8482 & 16 Enterococcus faecalis & YIT 2031 \\
\hline 3 Bacteroides vulgatus & A TCC 29327 & 17 Enterococcus faecium & YIT 2004 \\
\hline 4 Bacteroides vulgatus & ATCC 31376 & 18 Eubacterium aerofaciens & ATCC 25986 \\
\hline 5 Bacteroides thetaiotaoomicron & А ТCC 29148 & 19 Eubacterium biforme & VPI 9218 \\
\hline 6 Bacteroides ovatus & ATCC 8483 & 20 Lactobacillus acidophilus & 0070 \\
\hline 7 Bcteoides distasonis & ATCC 8503 & 21 Lactobacillus casei & YIT \\
\hline 8 Bacteroides merdae & ATCC 43184 & 22 Peptostreptococcus prevotii & ATCC 9321 \\
\hline 9 Bacteroides uniformis & ATCC 8492 & 23 Peptostreptococcus productus & ATCC 27340 \\
\hline 10 Bacteroides stercoris & ATCC 43183 & 24 Clostridium difficile & ATCC 17859 \\
\hline 11 Bacteroides eggerrthii & A TCC 27754 & 25 Clostridium innocuum & ATCC 14501 \\
\hline 12 Bacteroides caccae & ATCC 43185 & 26 Streptococcus lactis & YIT 2027 \\
\hline 13 Bifidobacterium longum & ATCC 15707 & 27 Streptococcus thermophilus & ATCC 19258 \\
\hline 14 Bifidobacterium breve & ATCC 15700 & 28 Veillonella alkalescens & ATCC 17745 \\
\hline
\end{tabular}

ATCC, American Type Culture Collection; VPI, Virginia Polytechnic Institute and State University ; YIT, Yakult Institute, Tokyo 
Table 3 Summary of the sequences of DNA Probes

\begin{tabular}{lcllc}
\hline \multicolumn{1}{c}{ Species } & Probe name & \multicolumn{1}{c}{ Sequence } & \multicolumn{1}{c}{ Target } & $\operatorname{Tm}\left({ }^{\circ} \mathrm{C}\right)$ \\
\hline Universal primer & PUNI & G(A/T)ATTACCGCGGC(G/T)GCTG & Positive control & 75.0 \\
B. fragilis & PFRA & GGTTCAGGCTAGCGCCC & B. fragilis & 78.3 \\
B. vulgatus & PVUL & ATTCCTTTATAAAAGAA & B. vulgatus & 42.1 \\
B. thetaiotaomicron & PTHE & GCGCCATTGACCAATAT & B. thetaiotaomicron & 61.4 \\
B. ovatus & POVA & GGCTCTCGCCCATTGAC & B. ovatus & 74.0 \\
B. distasinis & PDIS & TTCCCTTATAAAAGAGG & B. distasinis & 53.4 \\
B. merdae & PMER & GGCTCTCGGCCATTGAC & B. merdae & 74.0 \\
B. uniformis & PUNI & TGCTCACTTTATTCCCG & B. uniformis & 61.4 \\
B. stercoris & PSTE & AGACACACGTGGTCACT & B. stercoris & 65.5 \\
B. eggerrhii & PEGG & ACTCCACTTTATTCCCG & B. eggerrhii & 61.4 \\
B. caccae & PCAC & GTGGACTACTTTATTCCCAT & B. caccae & 63.8 \\
\hline
\end{tabular}

Tm : melting temperature

nol を加え， $-20^{\circ} \mathrm{Cにて} 2$ 時間沈殿を行った. 沈 殿物を $4{ }^{\circ} \mathrm{C}, 12,000 \mathrm{rpm}$ で20分間遠心させた 後, 真空遠心機で乾燥させた。 さらに300〜800 $\mu \ell の \mathrm{TE}$ に処理を行い，等量の $4 \mathrm{M} \mathrm{NaCl}$ を 加えた後, 水上で一晚沈殿させ， $4{ }^{\circ} \mathrm{C}, 12,000$ rpm にて遠沈させた．脱塩のため TE $300 \mu \ell$ ，

$2 \mathrm{M}$ sodium acetate $30 \mu \ell$ および ethanohl 750 $\mu \ell$ を加え, $-20^{\circ} \mathrm{C} て ゙ 2$ 時間反応させたのち再び 遠沈させ, $100 \%$ ethanohl にて洗浄, 回収し た.

\section{4. 塩基配列の決定}

抽出した16S - rRNA の増幅を, universal primer A ( $5^{\prime}-\mathrm{G}(\mathrm{A} / \mathrm{T})$ ATTACCGCGGC (G/T) GCTG - 3’2) ) および reverse transcriptase (RNA sequencing kit ; Boehringer Mannheim）を用いて行った. $2.0 \mathrm{mg} / \mathrm{mlk}$ に調整 したRNAに1. $5 \mu \ell の$ primer $(20 \mu \mathrm{g} / m \ell)$ を 加え, 滅菌蒸留水を加え $7.0 \mu \ell$ とし, $90^{\circ} \mathrm{C}$ で 1 時間反応させたのち $42^{\circ} \mathrm{C}$ で 5 分間反応させた. 次 に RNA asequencing kit を用いて32 P を標識 L, $8 \mathrm{M}$ urea $6 \%$ polyaxrylamide sequencing gel を用いて電気泳動させてそれぞれの菌 種の塩基配列を求めた.

5.オリゴヌクレオチドプローブの作成

求められた $16 \mathrm{~S}$ rRNA の部分塩基配列（約 250〜300塩基）を比較し，各々に特異的な領域を プローブとし DNA synthesizer (Applied Biosystems Model 380B）により合成した.

\section{6. プローブの標識}

digoxigenin（DIG）で標識された dideoxyuridine triphosphate Schmitz らの方 法4)を用いて probe の 3’末端に標識した。

7. 種特異性の検討 (Table 4)

Sambrook5) ら方法により変性させた RNA を nylin membrane (Gene Screen Plus, Du Pont）上にマイクロフィルター（Bio Dot, Bio $\mathrm{Rad})$ を用いて吸着させたのち ${ }^{6)}, 2$ 時間 $80^{\circ} \mathrm{C} に$ て乾燥させた。 次に membraneを, prehybridization 溶液 $(20 \times \mathrm{SSC} 1.5 \mathrm{~m} \ell, 50 \times$ Denhardt's solution $0.5 \mathrm{~m} \ell, 10 \%$ sodium dodecyl sulphate $0.5 \mathrm{~m} \ell, 10 \mathrm{mg} / \mathrm{m} \ell$ salmon sperm DNA $0.05 \mathrm{~m} \ell$, $25 \%$ dextran sulphate $2 m \ell$ ) の入ったポリエチ レンバッグに入れ, Table 3 に示した条件で 1 時間反応させ, prehybridization 溶液を hybridization 溶液 $(20 \times \mathrm{SSC} 1.5 \mathrm{~m} \ell, 50 \times$ Denhardt's $0.2 \mathrm{~m} \ell, \quad 10 \%$ sodium dodecyl. sulphate 0.5 $m \ell, 25 \%$ dextran sulphate $2 m \ell$, labeled probe $10 \mathrm{ng} / m \boldsymbol{l}$ ) で置換し,さらに 2 時間反応させ た. 反応終了後, membraneを $6 \times \mathrm{SSC} に て$ 洗 净し，それを Betascope (Betascope 603 blot analyzer : Betagen Cor., USA) を用いて検出 した.

8. 臨床材料のプローブによる検出

それぞれの粪便中腸内菌叢を同定したのち, Bacteroides 属のみをさらに純粋培養し, 前述の 方法により RNA の抽出を行い，それらに作成 
Table 4 Condition of hybridization

\begin{tabular}{lccc}
\hline Probe name & $\begin{array}{c}\text { Temperature of } \\
\text { prehybridization }\end{array}$ & $\begin{array}{c}\text { Temperature of } \\
\text { hybridization }\end{array}$ & Washing time \\
\hline PUNI & 55.0 & 55.0 & room temp, $5 \min \times 3 \rightarrow 65.0^{\circ} \mathrm{C}, 30 \mathrm{~min}$ \\
PFRA & 58.0 & 58.3 & room temp, $5 \min \times 3 \rightarrow 68.0^{\circ} \mathrm{C}, 30 \mathrm{~min}$ \\
PVUL & 50.0 & 35.0 & room temp, $5 \mathrm{~min} \times 2$ \\
PTHE & 41.4 & 41.4 & room temp, $5 \min \times 3 \rightarrow 51.4^{\circ} \mathrm{C}, 30 \mathrm{~min}$ \\
POVA & 54.0 & 54.0 & room temp, $5 \min \times 3 \rightarrow 64.0^{\circ} \mathrm{C}, 30 \mathrm{~min}$ \\
PDIS & 50.0 & 35.0 & $(-)$ \\
PMER & 54.0 & 54.0 & room temp, $5 \min \times 3 \rightarrow 64.0^{\circ} \mathrm{C}, 30 \mathrm{~min}$ \\
PUNI & 41.4 & 41.4 & room temp, $5 \min \times 3 \rightarrow 51.4^{\circ} \mathrm{C}, 30 \mathrm{~min}$ \\
PSTE & 45.5 & 45.5 & room temp, $5 \min \times 3 \rightarrow 55.5^{\circ} \mathrm{C}, 30 \mathrm{~min}$ \\
PEGG & 50.0 & 44.0 & room temp, $5 \min \rightarrow 54.0^{\circ} \mathrm{C}, 30 \mathrm{~min}$ \\
PCAC & 50.0 & 41.5 & room temp, $5 \mathrm{~min} \rightarrow 46.5^{\circ} \mathrm{C}, 30 \mathrm{~min}$ \\
\hline
\end{tabular}

\begin{tabular}{|c|c|c|c|}
\hline & & 373 & \\
\hline B. frasilis & ATCC 25285 & AAUAUUGGUCAAUGGGCGCUAGCCUGAACCAGCC & \\
\hline 8. wigatus & ATCC 8482 & AAUAUUGGUCAAUGGGCGAUGGCCUCAACCAGCC & \\
\hline B. thetaiotamicron & 7 ATCC 29148 & AAUAUUGCUCAAUGGCCC-AAGCCUUAACCAGCC & \\
\hline B.ovatus & ATCC 8483 & AAUAUUGGUCAAUGGGCGAGAGCCV-AACCAGCC & \\
\hline B.distasonis & ATCC 8503 & AAUAUUGGUCAAUGCCCGUAA-CCLUAACCAGCC & \\
\hline B.merdae & ATCC 43184 & AAUAUUGGUCAAUGGCCGAGAGCCU-AACCAGCC & \\
\hline B. Lniformis & ATCC 8492 & AAUAUUGGUCAAUGGKCGAGAG-C-GAACCAGCC & \\
\hline 8.stercoris & ATCC 43183 & AAUALUGGUCAAUGGACGAGAGUCUGAACCAGCC & \\
\hline B.escerrthii & ATCC 27754 & AAUAUUGGUCAAUGGACGAGAGUCU-AACCAGCC & \\
\hline \multirow[t]{2}{*}{ B. caccae } & ATCC 43185 & AAUALUUGGUCAAUGGA--AGAGUCUGAACCAGCC & \\
\hline & & 429 & 62 \\
\hline B. fragitis & ATCC 25285 & GUAACLUCUUUUAUUUAAGAAUAAAGUGCAGUAU & GUAUACUG \\
\hline B. wisatus & ATCC 8482 & GUAAACUUCUUUUUAUAAGGAAUAAAGUCGGGUAU & -CAUACC- \\
\hline B. thetaiotamicron & ATCC 29148 & GUAARCUUCUULUUAUAUGGGAUUAAAGUUUUCCAC & GUGUGCA- \\
\hline B.ovatus & ATCC 8483 & GUAAACUUCUUUUUAUAUGGSAAUAAAGUUUUUCCAC & GUGUGGAA \\
\hline B.distasonis & ATCC 8503 & GUAARCCUCUUUUAUAAGGGAAUAAAGU-CGG-AC & GUAUUCLU \\
\hline B.enerdae & ATCC 43184 & GUAAACUUCULWUAUACGGGAAUAAAGUGACCAC & GUGUCCCU \\
\hline B.uniforsis & ATCC 8492 & GUAAACUUCUUUUAAUAOGGGAAUAAAGUGAGCAC & GUGUGCC- \\
\hline B.stercoris & ATCC 43183 & GUAAACUUCUUWUAUACGGGAAUAAAGUGACCAC & GUGUGUCU \\
\hline B.esserrthii & ATCC 27754 & GUAAACUUCUUUUAAUACGGGAAUAAAGUGGAGUAU & GCAUACUC \\
\hline B. caccae & ATCC 43185 & GUAACUUCUUUUAUAUGGGAAUAAAGUAGUCCAC & GUGLGAAC \\
\hline
\end{tabular}

Fig. 1 Partial 16 S-rRNA sequence of various Bacteroides species

したプローブを反応させた.

\section{II. 結 果}

1. $16 \mathrm{~S}-\mathrm{rRNA}$ 塩基配列の決定（Fig. 1, Table 3)

10 種のバクテロイデスから抽出した 16 SrRNA より部分塩基配列を求めた（Fig. 1). この際 universal primer として, 全ての細菌に おいて非常に良く保存されている配列部分である E. coli の519-536番目の配列を用いた7)。部分塩 基配列としては約はか200塩基を決定し，それら を比較してそれぞれに特異的な配列を求め

(Fig. 1下線部)，それを probeとして合成した (Table 3 ).
2. 抽出 RNA のハイブリダイゼーション (Table 5)

作成した probe の特異性をみるために，各菌 種より抽出した RNA に対するハイブリダイ ゼーションを行った. PPRI, PFRA, PVUL, PDIS, PEGG, PCAC は各々の targetに対し て特異的に反応したが，PTHEは taget 以外に B. caccuae, POVA は B. thetaiotaomicron および B. caccae と, PMER は B. merdae, B. uniformis, B. stercoris, B. eggerrthii $\&$ も反応を示した，一方，PUNI および PSTE は target を含めいずれの菌種とも反応を示さな かった、これより, 同定不可能な B. thetaiotaomicron, B. ovatus, B. merdae, B. uniformis, B. stercoris をその他として扱った.

3.クローン病における糞便中腸内細菌叢の検 討

(1)総菌数および各菌群の変動（Table 6)

腸内細菌叢を叢菌数と各菌群に分けてそれぞれ 対照群と比較すると，CD 群では総菌数および嫌 気性菌群である Bacteroidaceae $(p<0.05)$, Peptococcaceae, Bifiobacterium $(\mathrm{p}<0.01)$ は有意に減少し，逆に Clostridium が有意に增 加した $(\mathrm{p}<0.01)$. 一方, 好気性菌群ではSteptococcus が有意に増加した（ $\mathrm{p}<0.01 ）$ 。た 各菌群の検出率をみると, Peptococcus, Bifidobacterium が有意に増加した $(\mathrm{p}<0.05)$ 以外 はとくに差はみられなかった。 
Table 5 Specificity of oligonucleotide probes

\begin{tabular}{|c|c|c|c|c|c|c|c|c|c|c|c|c|}
\hline \multirow{2}{*}{ Species } & \multirow{2}{*}{ Strain } & \multicolumn{11}{|c|}{ Specificity } \\
\hline & & PPRI & PFRA & PVUL & PTHE & POVA & PDIS & PMER & PUNI & PSTE & PEGG & $\mathrm{PCAC}$ \\
\hline Bacteroides fragilis & ATCC 25285 & + & + & - & - & - & - & - & - & - & - & - \\
\hline Bacteroides vulgatus & ATCC 8482 & + & - & + & - & - & - & - & - & - & - & - \\
\hline Bacteroides vulgatus & ATCC 29327 & + & - & + & - & - & - & - & - & - & - & - \\
\hline Bacteroides vulgatus & ATCC 31376 & + & - & + & - & - & - & - & - & - & - & - \\
\hline Bacteroides thetaiotaomicron & ATCC 29148 & + & - & - & + & + & - & - & - & - & - & - \\
\hline Bacteroides ovatus & ATCC 8483 & + & - & - & - & - & - & - & - & - & - & - \\
\hline Bacteroides distasonis & ATCC 8503 & + & - & - & - & - & + & - & - & - & - & - \\
\hline Bacteroides merdae & ATCC 43184 & + & - & - & - & - & - & + & - & - & - & - \\
\hline Bacteroides uniformis & ATCC 8492 & + & - & - & - & - & - & + & - & - & - & - \\
\hline Bacteroides stercoris & ATCC 43183 & + & - & - & - & - & - & + & - & - & - & - \\
\hline Bacteroides eggerrthii & ATCC 27754 & + & - & - & - & - & - & - & - & - & + & - \\
\hline Bacteroides caccae & ATCC 43185 & + & - & - & + & + & - & - & - & - & - & + \\
\hline Bifidobacterium longum & ATCC 15707 & + & - & - & - & - & - & - & - & - & - & - \\
\hline Bifidobacterium breve & ATCC 15700 & + & - & - & - & - & - & - & - & - & - & - \\
\hline Escherichia coli & ATCC 11775 & + & - & - & - & - & - & - & - & - & - & - \\
\hline Enterococcus faecalis & YIT 2031 & + & - & - & - & - & - & - & - & - & - & - \\
\hline Enterocuccus faecium & YIT 2004 & + & - & - & - & - & - & - & - & - & - & - \\
\hline Eubacterium aerofaciens & ATCC 25986 & + & - & - & - & - & - & - & - & - & - & - \\
\hline Eubacterium biforme & VPI 9218 & + & - & - & - & - & - & - & - & - & - & - \\
\hline Lactobacillus acidophilus & YIT & + & - & - & - & - & - & - & - & - & - & - \\
\hline Lactobacillus casei & YIT $\quad 0078$ & + & - & - & - & - & - & - & - & - & - & - \\
\hline Peptostreptococcus prevotii & ATCC 9321 & + & - & - & - & - & - & - & - & - & - & - \\
\hline Peptostreptococcus productus & ATCC 27340 & + & - & - & - & - & - & - & - & - & - & - \\
\hline Clostridium difficile & ATCC 17859 & + & - & - & - & - & - & - & - & - & - & - \\
\hline Clostridium innocuum & ATCC 14501 & + & - & - & - & - & - & - & - & - & - & - \\
\hline Streptococcus lactis & YIT 2027 & + & - & - & - & - & - & - & - & - & - & - \\
\hline Streptococcus thermophilus & ATCC 19258 & + & - & - & - & - & - & - & - & - & - & - \\
\hline Veillonella alkalescens & ATCC 17745 & + & - & - & - & - & - & - & - & - & - & - \\
\hline
\end{tabular}

ATCC, American Type Culture Collection ; VPI, Virginia Polytechnic Institute and State University ; YIT, Yakult Institute, Tokyo

Table 6 Isolation of bacteria from feces of control and Crohn's disease

\begin{tabular}{lccccc}
\hline \multicolumn{1}{c}{ Total } & \multicolumn{2}{c}{ Control $(\mathrm{n}=10)$} & \multicolumn{2}{c}{ Crohn's disease $(\mathrm{n}=7)$} \\
\hline (Obligate anaerobes) & $11.1 \pm 0.1^{\text {(a) }}$ & $(100)$ (b) & $10.0 \pm 0.3^{* *}$ & $(100)$ \\
Bacteroidaceae & & & & & \\
Peptococcaceae & $10.6 \pm 0.3$ & $(100)$ & $6.9 \pm 3.7^{*}$ & $(88)$ \\
Bifidobacterium & $9.3 \pm 0.6$ & $(90)$ & $0 \pm 0{ }^{* *}$ & $(0)^{*}$ \\
Veillonella & $10.5 \pm 0.3$ & $(100)$ & $0.7 \pm 2.1^{* *}$ & $(13)^{*}$ \\
Clostridium & $7.1 \pm 0.9$ & $(60)$ & $4.9 \pm 4.2$ & $(63)$ \\
\hline Lactobacillus & $4.0 \pm 1.3$ & $(100)$ & $7.7 \pm 3.2^{*}$ & $(88)$ \\
(Facultive anaerobes) & $6.9 \pm 1.3$ & $(100)$ & $5.9 \pm 3.3$ & $(88)$ \\
Enterobacteriaceae & $8.0 \pm 0.7$ & $(100)$ & $7.7 \pm 1.4$ & $(100)$ \\
Streptococcus & $6.4 \pm 1.6$ & $(100)$ & $8.9 \pm 1.4^{* *}$ & $(100)$ \\
Yeasts & $4.1 \pm 1.0$ & $(40)$ & $2.4 \pm 3.0$ & $(50)$ \\
Staphylococcus & $0 \pm 0$ & $(0)$ & $1.3 \pm 2.5$ & $(25)$ \\
\hline
\end{tabular}

(a) Mean $\pm S$. D. of log No. of bacteria per $g$

(b) Frequency of occurrence $(\%)$

* $\mathrm{P}<0.05, * * \mathrm{P}<0.01$ 
Table 7 Isolation of Bacteroides species from feces

\begin{tabular}{lrrrr}
\hline & \multicolumn{2}{c}{ Control $(n=10)$} & \multicolumn{2}{c}{ Crohn's disease $(n=7)$} \\
\hline Bacteroides & \multicolumn{1}{c}{ ( a $)$} & (b) & ( 1 ) & (b) \\
\cline { 2 - 5 } fragilis & $9.7 \pm 0.3$ & 8.1 & $7.1 \pm 3.8$ & $97.3^{* *}$ \\
vulgatus & $10.5 \pm 0.7$ & 51.9 & $5.5 \pm 4.6^{*}$ & $2.6^{* *}$ \\
distasonis & $9.2 \pm 1.2$ & 2.5 & $2.3 \pm 3.9^{* *}$ & 0.03 \\
eggerrthii & $9.9 \pm 0.5$ & 13.0 & $0 \pm 03^{* *}$ & $0.0^{* *}$ \\
caccae & $10.1 \pm 0.7$ & 19.3 & $2.9 \pm 4.8^{* *}$ & $0.06^{* *}$ \\
other & $9.5 \pm 0.3$ & 5.2 & $1.2 \pm 3.1^{* *}$ & $0.01^{*}$ \\
\hline
\end{tabular}

(a) Mean \pm S, D. of $\log$ No, of bacteria per $g$

(b) Percentages in comp9arison of total counts $* \mathrm{P}<0.05, * * \mathrm{P}<0.01$

(2)クローン病におけるバクテロイデス属の種の 検討 (Table 7)

バクテロイデスの各菌種の菌数をみると, 対照 群に比較し CD 群で咸少を認めた。しかし対照 群の糞便と比へ， $\mathrm{CD}$ 群では軟便〜水様便で菌数 が希积されている可能性があるため, 総菌数に占 める各菌種の割合で比較すると，対照群ではB. vulgatus が51. $9 \%$ と最も高く, 次いでB. caccae $19.3 \%$, B. eggerrthii $3.0 \%$, B. fragilis $8.1 \%$, B. other $5.2 \%$, B. distasonis $2.5 \%$ の 順であったが，CD 群では B. fragilis が97. 3\% 上最者多く，次いでB. vulgatus $2.6 \%, B$. caccae $0.06 \%$, B. distasonis $0.03 \%$, B. other 0.01\%, B. eggerrthii 0\%と，その構成に変動 がみられ，特にB，fragilis が著明に増加したの に対し，他の菌種がすべて減少した。

\section{III. 考 察}

最近，本邦におけるクローン病は年々増加傾向 にあるが，その成因については未だ不明で治療が 困難なことが多くいわゆる難病の一つに指定さ れ，擪生省に研究班が編成されるなど，その病 因，病態の解明に多くの努力がなされている。本 症は腸管粘膜や腸管壁の諸要因および全身的な免 疫学的諸機構などの他, 腸内最近叢の变動やそれ ら最近による感染および毒素産生などが，相互に 作用しあった結果成立するものと考えられてお り, 本症と腸内最近叢の構成との関連を研究する ことは重要である．しかし腸内フローラを構成す る菌種は極めて複雑で，選択培地によっても同定
は属または科レベルまでで，菌種の同定となると かなりの熟練が必要で, 従来実施されていた最近 の分類・同定は，その菌株の持つ表現形質を調 べ，既に報告のある菌種の中からどの菌種の性状 に最も近いかを推定するなど主観的要素も多く含 んでいた.この菌種同定における問題点を解決す るための一つの方法としては，モノクローナル抗 体やポリクーナル抗体を用いることである が8,9)，それでもすべてを区別することは不可能 であり，これらの事実がこれまでの研究において 支障となっている，そこで近年，それぞれの細菌 のみが有する特定遺伝子配列を求め，それらをフ ローブとして未知試料とハイブリダイゼーション を行い，相補性が認められるかどうかで同定する DNA ハイブリダイゼーション法が導入されるよ うになった. DNAハイブリダイゼーション法は 培養したコロニーを用いたり，あるいは䔬便・膿 汁などの臨木材料から直接同定することが可能で ある. 現在この方法は, 病原性に関与する最近の 遺伝子をプローブとしてヒトの病原菌・食中毒最 近の同定などに利用されている.

これまでクローン病における腸内フローラには Bacteroides fragilis group が最優勢に出現す るとの報告がみられることから，本疾患とバクテ ロイデス属とのかかわりを解明する研究の一環と して，バクテロイデス属の10菌種に対して約 200 塩基 ${ }^{10)}$ の部分塩基配列を決定し，その相補的配列 をプローブとして作成し，クローン病疾患者にお ける䔬便中バクテロイデス属の種の变動について 検討した。 
作成した10個のプローブのうち, PFRA, PVLU, PDIS, PEGG, PCACの5つのプロー ブが種特異性を示したが，PTHE，POVA， PMER, PUNI, PSTE では特異性を得られな かった，特異性のなかったプローブは他の菌種と $1 \sim 2$ 塩基の違いであったが，通常オリゴヌクレ オチドプローブでは 1 塩基の違いがあれば検出可 能であることから11)，おそらく hybridization や prehybridization あるいは washing の段階に おける温度設定に影響されたものと推察される。

糞便中腸内フローラの変動におりる検討では, $\mathrm{CD}$ 群は総菌数および主要嫌気性菌群である $\mathrm{Ba}$ cteroidaceae, Bifidobacterium, Peptocaccaceae は隇少し，逆に好気性菌の Clostridium が 増加しており，これまでの報告とほぼ一致し た ${ }^{12-15)}$. Wensinck 16,17) は，回腸末端型に特徵 的な腸内フローラの変化として, Bacteroides, Fusobacterium や球菌様桿菌 (Coccoid : Eubacterium rectale, E. contortum, Peptostreptococcus productus）が健常人に比べて有意 に多く，その中でも特に球菌様桿菌が本症疾者の 血清と特異的に凝集することから，これらと本症 の発症との関連性を示唆しているが，著者の成績 では本症疾者の粪便よりこれらの嫌気性菌が高頻 度に検出されず，この菌が本症の発症への関与は 否定的であった。

通常, 腸内フローラの検討は粪便 $1 \mathrm{~g}$ 中の菌数 により比較されることが多いが，本疾患の様に一 日排便回数や粪便中水分含有量が増加している場 合などは，湿重量当たりの各菌群の絶対数の比較 は困難であるため，一日当たりに排泄される菌数 で検討する必要性を指摘した報告や18), 総菌数に 対する各菌群の占める割合で検討した結果がみら れている13,19,20).そこで総菌数に占める各菌種の 占有率で比較すると，B，fragilis は対照群8.1\% に対し，CD 群では97.3\%と有意に増加し過去の 報告と一致していたが，他の菌種においてはすべ て対照群よりも減少を示したいた点で異なってい た。

これまで，クローン病におけるバクテロイデス 属の増加を Elemental diet（ED）による影響 とした報告もみられる12,13)。緩解期は症例数が少 なく今回の検討から除いているが，その結果は全
例 ED 療法が継続して行われているにも関わら ず，B. fragilis 占有率は緩解期 $36.2 \%$, 活動期 $96,7 \%$, 対照群 $8.1 \%$ と緩解期は活動期と緩解期 の中間に位置しており，また活動期の病型や排便 回数, activity indexにもとくに差がないことか ら，ED の影響というよりも本菌種がクローン病 の病態に関与している可能性が示唆された.

本疾患におていB. fragilis が他のバクテロイ デス属に比べ高率に出現することにより，腸内腐 敗産物であるアンモニアや硫化水素の増加を導く 可能性が考えられ，クローン病の病態や治療法の 解明において腸内菌丵とくにバクテケロイデス属 とのかかわりを追求する必要があるものと考えら れた。

結語

ヒト䔬便中に常在するバクテロイデス属のう ち, B. fragilis, B. vulgatus, B. caccae, B. distasonis, B. eggerrthii, に対し種特異性を 有するプローブを作成した。これらを用いてクー ン病疾患者粪便中のバクテロイデス属の種の变動 を検討した結果，B，fragilisのクローン病の病 態への関与が示唆された。

稿を終えるにあたり御指導, 御校閲を睗りました恩 師斎藤利彦教授に深甚なる謝意を捧げます。また直接 御教示, 御助言を頂きました宮岡正明助教授に潹く感 謝いたしますと共に，本研究について直接御指導頂き ました窪田良彦博士並びに多大なる御協力を頂いた居 室員各位に深く感謝いたします。さらに研究にあたり 御指導, 御鞭撻を頂いたヤクルト中央研究所の諸先生 方に厚く御礼申し上げます.

なお, 本論文の要旨は第36回日本消化器病大会, 第 70回日本細菌学会にて発表した。

\section{文献}

1) Keighley MRB, Arabi Y, Dimock F : Influence of inflammatory bowel disease on intestinal microflora. Gut $19: 1099-1104$, 1978

2) Shah H, Collins DM : Prevotella, a new genus to include Bacteroides melaninogenicus and related species formerly classified in the genus Bacteroides. Int $\mathrm{J}$ Syst Bacteriol 40:205-208, 1990

3 ）光岡知足: 晹内細菌の世界, 新装改訂版。東 京, 叢文社, 1984: p 13-41

4) Schmitz GG, Walter T, Seibl R : Nonra- 
dioactive labeling of oligonucleotide in vitro with the hapten digoxigenin by tailing with terminal transferase. Ann Biochem $192: 222-231,1991$

5 ) Samabrook J, Maniatis T, Fritsh E : Molecular cloning : a laboratory manual. 2 nd ed. Cold Spring Harbor, Laboratory Press, NY 1989, 7 : p 54-55

6) Salama M, Sandine W, Giovannoni S : Development and application of oligonucleotide probes for identification of Lactococcus lactis subsp. Appli Environ Microbiol $57: 1313-1318,1991$

7) Noller HF, Woese CR : Secondary structure of $16 \mathrm{~S}$ ribosomal RNA. Science 212: 403-411, 1981

8) Bonta Y, Zambon JJ, Genco RJ, et al : Rapid identification of periodontal pathogens in subgingival plaque : comparison of indirect iommunofluorescence microscopy with bacterial culture for detection of Actinobacillus actinomycetemcomitans. J Dent Res 64:793-798, 1985

9 ) Zambon JJ, Slots S, Genco RJ : Serology of oral Actinobacillus actinomycetemcomitans and serotype distribution in human periodontal disease. Infect Immun $41: 19-27,1983$

10) Maysoon S, William $S$, Stephen G, et al : Development and application of pligonucleotide probes for identification of Lactococcus lactis subsp. cremoris. Appli Environ Microbiol $157: 1313-1318,1991$

11) Wallace RB, Shaffer JS, Murphy RF : Hybridization of syntheric oligodeoxyri- bonucleotides to $\Phi \times 174$ DNA : the effect of a single base pair mismach. Nucleic Acids Res $6: 3543-3557,1979$

12）辨野義己, 光岡知足, 松枝啓ほか：クローン病 における ED の腸内菌叢におよぼす影響。 JJPEN $7: 309-313,1985$

13）鈴木邦彦，樋渡信夫，今井伸行：経腸栄養と腸 内フローラ. 光岡知足編. 腸内フローラと食物 因子. 東京, 学会出版センター, 1984, p 133149

14）辨野義己, 光岡知足：ヒ卜の健康と病気におけ る腸内フローラの構成. 光岡知足編. 腸内フ ローラの生態上役割. 東京, 学会出版セン 夕-, 1990, p 63-67

15）下山孝，里見，大野忠嗣ほか：厚生省特定疾患 クローン病調査研究班昭和56年度業績集 : 347, 1982

16) Wensinck F, Vande Merwe JP : Serumagglutinius to Eubacterium and Peptococcus species in Crohn's and other disease. J Hyg $87: 13-24,1981$

17) Wensinck F, Vande Merwe JP : The fecal flora of patients with Crohn's disease. J Hyg (camb) 87: 1-12, 1981

18）下山 孝, 大野忠嗣, 樽林 尚ほか: IBDに 対する治療による腸内菌叢の变動. 最新医学 $38: 1490,1983$

19）窖田良彦：大腸腺種および大腸癌患者における 䔬便中腸内細菌叢の検討：日消病会誌 38 ： $771-779,1991$

20）高橋秀理：潰瘍性大腸炎の粪便中腸内細菌叢の 検討：東医大雑誌 $49: 57,1991$

21）鈴木邦彦：クローン病患者の䝴便菌叢一未治療 および ED 治療による变動について，日消病 会誌 $80: 1144,1983$ 


\title{
A Study on Fecal Intestinal Flora in Crohn's Disease with Using Oligonucleotide Probes
}

\author{
K. Watanabe \\ Forth Department of Internal Medicine, Tokyo Medical College, Tokyo \\ (Director : Prof. Toshihiko Saitoh)
}

In recent years, potential association of species variability of the genus Bacteroides with inflammatory bowel disease has been the focus of attention. In clinical practice, however, it is often difficult to identify causative pathogens. Using DNA probes specific for Bacteroides fragilis, B. vulgatus, B. distasonis, B eggerrthii, and B. caccae, species variability of the genus Bacteroides was investigated in Crohn's disease (CD) ; the cell counts were generally decreased in the CD group. When proportion of individual species to the total cell counts of the genus Bacteroides were determined, B. fragilis was significantly increased, but other species were significantly decreased in comparison with the control group. The results of this study suggest that Bacteroides fragilis is associated with the pathogenesis of $\mathrm{CD}$. 